\title{
The effect of calcium propionate supplementation on performance, meat quality, and mRNA expression of finishing steers fed a high-concentrate diet
}

\author{
X.Z. Zhang ${ }^{1}$, Q.X. Meng ${ }^{1}$, L. Lu' ${ }^{2}$, Z.L. Cui ${ }^{1}$ and L.P. Ren ${ }^{1,3}$ \\ ${ }^{1}$ China Agricultural University, College of Animal Science and Technology, State Key Laboratory of Animal Nutrition \\ Beijing 100193, China \\ ${ }^{2}$ Beijing University of Agriculture, College of Animal Science and Technology, Beijing 102206, China
}

KEY WORDS: steers, diet, calcium propionate, performance, meat quality, mRNA expression

Received: 18 August 2014

Revised: 29 April 2015

Accepted: 15 June 2015

${ }^{3}$ Corresponding author:

e-mail: renlp@cau.edu.cn

\begin{abstract}
The effects of calcium propionate supplementation on performance, meat quality, and mRNA expression of Wagyu steers were investigated. Eighteen steers ( $635 \pm 20 \mathrm{~kg} ; 18 \pm 1$ month old) were randomly divided into two groups: control (CG, without calcium propionate) and experimental (CaP, $200 \mathrm{~g}$ calcium propionate per steer per day). All steers were reared for 51 days under the same production system and then slaughtered at a final body weight of $680 \pm 18 \mathrm{~kg}$. The results showed no significant differences in dry matter intake, daily gain, or feed conversion ratio between the CaP and CG groups $(P>0.05)$. The treatments did not significantly affect the $\mathrm{pH}$, drip loss, cooking loss, Warner-Bratzler shear, protein, fat and ash contents in meat $(P>0.05)$. The erucic acid (C22:1) content in group $\mathrm{CaP}$ was significantly lower than in CG $(P<0.05)$. The content of polyunsaturated fatty acids (PUFA) in CaP showed a decreasing trend compared with CG $(P=0.06)$. The expression of genes for peroxisome proliferator-activated receptor $\mathrm{Y}$ (PPARG) and CCAAT/ enhancer binding protein a (CEBPA), which are involved in adipogenesis, was significantly higher in group $\mathrm{CaP}$ than in $\mathrm{CG}(P<0.05)$. The results indicate that supplementing calcium propionate did not affect animal performance, but changed the composition of meat fatty acids, especially PUFA and erucic acid, and could trigger upregulation of PPARG and CEBPA mRNA expression levels, which could cause long-term activation of adipogenesis. Therefore, the results of the present study point to the possibilities of improving meat quality through calcium propionate supplementation of the diet.
\end{abstract}

\section{Introduction}

In ruminants, dietary carbohydrates are fermented by rumen microorganisms into volatile fatty acids. Propionate is the primary precursor for glucose synthesis, and can supply $90 \%$ of this sugar in these animals (Bergman, 1975). Glucose provides energy, as well as acetyl units (a synthetic fat precursor), half of which are used for synthesis of intramuscular fat, which improves meat quality (Smith and Crouse, 1984).

Wagyu steers are famous for their genetic predisposition for intense marbling (intramuscular fat in the cross section of the longissimus muscle) and 
the production of meat with a high percentage of oleaginous unsaturated fats (Mir et al., 1999; Wheeler et al., 2004). High marbling levels improve the palatability and acceptability of beef by affecting its composition and tenderness (Nishimura et al., 1999). Marbling is one of the determinants of beef quality in the standards binding in the USA (USDA, 1989) and Japan (JMGA, 1988). Depositing body fat, especially intramuscular fat in finishing cattle, requires high-grain diets supplying large amounts of energy. Lee-Rangel et al. (2012) found that calcium propionate could be used to replace part of the energy supplied by grain in diets for finishing lambs. Liu et al. $(2009 \mathrm{a}, \mathrm{b})$ found that adding calcium propionate promoted rumen fermentation, increased feed digestibility, and maintained the energy balance of lactating dairy cows.

Numerous recent studies have suggested that propionate could act as a signal molecule inducing preadipocyte differentiation (Lee and Hossner, 2002; Xiong et al., 2004; Hong et al., 2005). Wan et al. (2009) found that supplementing propionate could increase peroxisome proliferator-activated receptor $\gamma(P P A R G)$ and CCAAT/enhancer binding protein $\alpha$ (CEBPA) mRNA expression of bovine intramuscular preadipocytes in culture. CCAAT/enhancer binding proteins, $\mathrm{C} / \mathrm{EBPs}$, including $\mathrm{C} / \mathrm{EBP} \alpha, \mathrm{C} / \mathrm{EBP} \beta$ and $\mathrm{C} / \mathrm{EBP} \delta$, were the first transcription factors shown to play an important role in the process of adipocyte differentiation (Lekstrom and Xanthopoulos, 1998). PPARs have three haplotypes: PPAR $\alpha$, PPAR $\beta$ and PPAR $\gamma$ (Issemann and Green, 1990). Many studies have found that PPAR $\gamma$ was required for the differentiation of adipose tissue in vivo and in vitro (Kutoba et al., 1999; Rosen et al., 1999).

The hypothesis of this study is that calcium propionate acting as an energy source and signal molecule could improve finishing efficiency and meat quality; this would be tested by examining growth performance, meat quality, and mRNA expression of adipogenic marker genes in the longissimus muscle of finishing steers.

\section{Material and methods}

\section{Animals and experimental design}

Eighteen medium-frame Wagyu steers $(635 \pm 20$ $\mathrm{kg} ; 18 \pm 1$ month old) were divided into two groups in a completely randomized design and housed in a tie-stall facility. The animals were handled in strict accordance with the guidelines approved by the Animal Welfare Committee of China Agricultural University (Permit Number: DK1008). The treatments were: control group (CG, without calcium propionate) and experimental group (CaP, $200 \mathrm{~g}$ calcium propionate per steer per day). The calcium propionate $(99.26 \%)$ was from Dong Xin chemical plant (Teng Zhou, Shan Dong Province, China). The trial period lasted 51 days, which included a 7-day introductory period and a 44-day experimental feeding period. The adjustment period of 1 week allowed the steers to become acclimated to routine feeding and to allot time for proper diet adjustment before the experiment. During the adjustment period, calcium propionate was gradually increased in the diet. In the experimental feeding period, calcium propionate was supplemented by adding it to $15 \%$ of concentrate feed and supplied separately. Because the steers were fed individually ad libitum, the Ca propionate was mixed with part of the concentrate in order to make sure that $200 \mathrm{~g} \mathrm{Ca}$ propionate would be eaten completely. The feeding procedure was: first, $200 \mathrm{~g}$ of Ca propionate mixed with part of the concentrate feed (experimental group) or the same weight of concentrate feed (control group); next the total mixed ration was given to the cattle ad libitum after all steers eat all feeds given in the first step. Fifteen percent concentrate was the appropriate proportion to mix with $200 \mathrm{~g}$ of Ca propionate.

\section{Diets and feeding management}

The basal diet met the NRC (2000) requirements for $600 \mathrm{~kg}$ Wagyu with a weight gain of $1.0 \mathrm{~kg} \cdot \mathrm{d}^{-1}$. The basal diets consisted of $25 \%$ maize stover silage and $75 \%$ concentrate (Table 1 ). The steers were individually fed ad libitum at 06:00 and 17:00 and had free access to fresh water throughout the experimental period.

Table 1. Ingredients and nutrient level of the basal diet (DM)

\begin{tabular}{lclc}
\hline Ingredients & $\mathrm{g} \cdot \mathrm{kg}^{-1} \mathrm{DM}$ & Nutrients level & Content \\
\hline Maize stover silage & 250 & $\mathrm{NE}_{\mathrm{m}}{ }^{2}, \mathrm{Mcal} \cdot \mathrm{kg}^{-1}$ & 2.01 \\
Maize & 523.5 & $\mathrm{NE}_{\mathrm{g}}{ }^{3}, \mathrm{Mcal} \cdot \mathrm{kg}^{-1}$ & 1.36 \\
Cottonseed meal & 40 & $\%$ : CP & 12.59 \\
Brewer's grains & 160 & $\mathrm{NDF}$ & 40.86 \\
Magnesium oxide & 2.5 & $\mathrm{ADF}$ & 18.22 \\
Limestone & 6 & $\mathrm{EE}$ & 4.44 \\
Sodium bicarbonate & 10 & $\mathrm{Ca}$ & 0.66 \\
Calcium phosphate & 1 & $\mathrm{P}$ & 0.33 \\
Salt & 5 & ash & 4.51 \\
Premix & 2 & &
\end{tabular}

${ }^{1}$ contained: mg: Co 198, Cu 9228, Fe 80376, I 754, Mn 58, Se 366, Zn 66350; 2,3 calculated based on NRC (2000); DM - dry matter, $C P$ - crude protein, NDF - neutral detergent fibre, ADF - acid detergent fibre, $\mathrm{EE}$ - ether extract, $\mathrm{NE}_{\mathrm{m}}$ - net energy for maintenance, $\mathrm{NE}_{\mathrm{g}}$ - net energy for growth 


\section{Feed analysis}

Total mixed ration (TMR) feed samples were collected once a week and dried at $65^{\circ} \mathrm{C}$ in an air oven, then ground through a $1-\mathrm{mm}$ screen using a Wiley Mill (A.H. Thomas Co., Philadelphia, PA, USA). Ground samples were used for determining dry matter $(\mathrm{DM})$, crude protein $(\mathrm{CP})$, ether extract (EE), ash, calcium and phosphorus according to AOAC (1999) methods (Table 1). Neutral detergent fibre (NDF) and acid detergent fibre (ADF) analyses were carried out according to Van Soest et al. (1991).

\section{Growth}

The body weight of all steers was measured (at the beginning and at the end of the finishing period) and refusals were recorded every day to calculate the average daily gain [ADG: (final body weight - initial body weight)/days], average dry matter intake (DMI) and feed conversion ratio (FCR: DMI/ ADG).

\section{Sampling procedures}

At the end of feeding trail, all experimental steers were starved for $12 \mathrm{~h}$ before they were loaded and transported $5 \mathrm{~km}$ to a commercial slaughterhouse. Efforts were made to minimize suffering during transport and slaughter. Briefly, wide ramps with $11^{\circ}$ slopes were used for loading and unloading steers, and the transport vehicle was equipped with non-slip flooring. Pre-slaughter handling systems were used to encourage smooth movement of steers. Steers were electrically stunned before slaughtering; they were restrained in an upright position with the head held fast and the neck exposed in a suitable position for incision of the throat. The knife has a long, extremely sharp blade. After slaughter, a portion of the longissimus muscle (1-2 g) from the $12^{\text {th }}$ to $13^{\text {th }}$ rib of the carcass was sampled immediately for RNA extraction. The sample tools were soaked in $1 \%$ diethyl pyrocarbonate in water to remove RNase. The samples were placed in sterile tubes $\left(\right.$ Corning ${ }^{\circledR}$ cyrogenic vials, cat No. 430659, Corning Inc., NY, USA), packed in gauze bags and stored in liquid nitrogen. After a 72 -h post mortem period $\left(1^{\circ} \mathrm{C}\right.$ to $4^{\circ} \mathrm{C}$ ), the longissimus muscle from the $12^{\text {th }}$ to $13^{\text {th }}$ rib was sampled to determine meat quality.

\section{Meat quality and fatty acid analysis}

The $\mathrm{pH}$ of the longissimus muscle was measured directly using a $\mathrm{pH}$ meter (Eutech Instruments, $\mathrm{pH}$ Spear, Thermo Fisher Scientific Inc., Shanghai, China). One steak was cut into $15 \mathrm{~mm} \times 15 \mathrm{~mm}$ $\times 30 \mathrm{~mm}$ and then suspended at $4^{\circ} \mathrm{C}$ for $48 \mathrm{~h}$ to calculate drip loss. Another steak was vacuum- packed in a polyethylene bag and heated at $80^{\circ} \mathrm{C}$ until the internal temperature reached $70^{\circ} \mathrm{C}$ to calculate the cooking loss percentage, then divided into six $1 \mathrm{~cm}$-diameter round strips for Warner-Bratzler shear force measurement (Salter Brecknell, Model 2356X Manhattan, KS, USA). The meat samples were lyophilized and pulverized for the determination of chemical composition, including moisture, protein, fat and ash according to AOAC (1999) methods. The chemical composition was determined after removing the connective tissue, subcutaneous fat and intermuscular fat. Therefore, the fat content was considered to reflect the intramuscular fat.

Fatty acids were determined by the use of a gas chromatography and, therefore, were first transformed into fatty acid methyl esters (FAMEs). FAMEs were prepared according to O'Fallon et al. (2007) with small modifications because of the high fatty acid content in Wagyu meat. The changes were in the weight of the meat samples and duration of manual shaking to completely extract fatty acids. The successive steps were: $1 \mathrm{ml}$ of C13:0 internal standard $\left(0.5 \mathrm{mg} \mathrm{C} 13: 0 \cdot \mathrm{ml}^{-1} \mathrm{MeOH}\right), 0.7 \mathrm{ml} 10 \mathrm{~N}$ $\mathrm{KOH}$ in water, and $5.3 \mathrm{ml} \mathrm{MeOH}$ were added to tubes containing $0.2 \mathrm{~g}$ of meat sample. After vortexing the tubes were incubated at $55^{\circ} \mathrm{C}$ in a water bath. The tubes were then cooled to below room temperature in a cold tap water bath and $0.58 \mathrm{ml} 12 \mathrm{~N} \mathrm{H}_{2} \mathrm{SO}_{4}$ in water was added. The tubes were vortexed again and incubated at $55^{\circ} \mathrm{C}$ for $1.5 \mathrm{~h}$ with vigorous manual shaking for $5 \mathrm{~s}$ every $10 \mathrm{~min}$ with precipitated $\mathrm{K}_{2} \mathrm{SO}_{4}$ appearing. After FAME synthesis, the tubes were cooled in a cold tap water bath. Then $3.0 \mathrm{ml}$ of hexane was added and the tubes were vortexed for 8 min and centrifuged for $5 \mathrm{~min}$ at $3000 \mathrm{rpm}$.

The hexane layer containing the FAMEs was transferred into $2 \mathrm{ml}$ gas chromatography (GC) vials. The vials were capped and stored at $-20^{\circ} \mathrm{C}$ until GC analysis. The fatty acid composition of the FAMEs was determined according to the O'Fallon et al. (2007) method. Fatty acids were identified by comparing their retention times to those of methylated fatty acid standards (Sigma, Sigma-Aldrich Shanghai Trading Co. Ltd., Shanghai, China). Fatty acid concentrations were expressed as $\mathrm{mg} \cdot \mathrm{g}^{-1}$ of sample. The fatty acid composition of FAMEs was determined by capillary $\mathrm{GC}$ on a SPTM-2560, $100 \mathrm{~m} \times 0.25 \mathrm{~mm} \times 0.20 \mathrm{~m}$ capillary column (Supelco, Bellefonte, PA, USA) installed on a Agilent 6890 GC (Agilent Technologies, Santa Clara, CA, USA). The initial oven temperature of $140^{\circ} \mathrm{C}$ was held for $5 \mathrm{~min}$, subsequently increased to $240^{\circ} \mathrm{C}$ at a rate of $4^{\circ} \mathrm{C} \cdot \mathrm{min}^{-1}$, then held for $20 \mathrm{~min}$. Helium was used as the carrier gas at a flow rate of $0.5 \mathrm{ml} \cdot \mathrm{min}^{-1}$, and the column head pressure was 
$280 \mathrm{kPa}$. The injector and the detector were set at $250^{\circ} \mathrm{C}$ and $260^{\circ} \mathrm{C}$, respectively. The split ratio was $30: 1$.

\section{Total RNA extract and relative quantitative real-time polymerase chain reaction}

Total RNA was extracted using the TRIzol (Bioteke Corporation, Beijing, China) reagent. The concentration and the OD260 and OD280 values of the extracted RNA were determined using an ultraviolet spectrophotometer Nanodrop ND-1000 (Nanodrop Technologies, Inc., Willmington, DE, USA). The quality of the total extracted RNA was checked by agarose gel electrophoresis.

The cDNA was produced from $2 \mu \mathrm{g}$ RNA using a super RT Kit PR6601 (Bioteke Corporation, Beijing, China) and the protocol recommended by the manufacturer. The primer sequences of the target genes, PPARG, CEBPA, and a house-keeping gene, GAPDH (glyceraldehyde-3-phosphate dehydrogenase), were designed using Primer Express 2.0 software (Aplied Biosystems, Stockholm, Sweden).The primer sequences were: PPARG, forward 5'-CGACCAACTGAACCCAGA-3' and reverse 5'-AGCGGGAAGGACTTTATGT-3'; CEBPA, forward 5'-CCCGATAAAGCCAGCACT-3' and reverse 5'-CCACCTTCACGCAGAACA-3'; GAPDH, forward 5'-GGTGATGCTGGTGCTGAGT-3' and reverse 5'-ATGATGACCCTCTTGGCG-3'. Quantitative real-time PCR (qPCR) was used to analyse the expression of PPARG (accession number: BC116098.1), CEBPA (accession number: BC149006.1), and the housekeeping gene, GAPDH (accession number: NM 001034034.1), which was used as an endogenous control (Smith et al., 2012). The qPCR reaction system had the following parameters: $1 \mu$ of the cDNA template, $10 \mu \mathrm{l}$ of $2 \times$ SYBR real-time PCR premixture PR7002, (BioTeke, Beijing, China), $0.4 \mu \mathrm{l}$ of the forward primer, $0.4 \mu \mathrm{l}$ of reverse primer, and $8.2 \mu \mathrm{l}$ to $20 \mu \mathrm{l}$ of $\mathrm{dd}_{2} \mathrm{O}$. The reaction liquid was transferred into a 96-well thermal sealing ring. The BIO 584BR detection system (Bio-Rad Co., Ltd., CA, USA) was used with the thermal cycling variables recommended by the manufacturer: one cycle at $94^{\circ} \mathrm{C}$ for $5 \mathrm{~min}, 45$ cycles of denaturation at $94^{\circ} \mathrm{C}$ for $15 \mathrm{~s}, 60^{\circ} \mathrm{C}$ for $15 \mathrm{~s}$ and for annealing extension at $72^{\circ} \mathrm{C}$ for $15 \mathrm{~s}$. The last extension step was performed at $72^{\circ} \mathrm{C}$ for $10 \mathrm{~min}$.

A standard curve was generated separately for the housekeeping gene and each target gene. Five standard solutions differing in concentration were made by 10 -fold dilutions. To reduce the error between the qPCR assays, every qPCR assay was used to make a standard curve. The results of PPARG/
$G A P D H$ and $C E B P A / G A P D H$ were expressed by -Lg10 copy number.

\section{Statistical analysis}

The effects of dietary calcium propionate supplementation on growth performance, meat quality, and gene expression in the longissimus muscle of finishing steers fed a high-energy diet were evaluated using ANOVA of the generalized linear model (GLM) procedures of SAS 9.0 (SAS Institute Inc., 2002). The differences between groups were analysed in terms of least square group means using a t-test. Differences were considered significant at $P<0.05$, and not significant at $P>0.1$.

\section{Results and discussion}

\section{Effect of dietary calcium propionate supplementation on performance}

The results of the present study show that dietary calcium propionate supplementation did not affect dry matter intake (DMI), average daily weight gain (ADG), or feed conversion ratio (FCR) during the experimental periods $(P>0.05$; Table 2$)$. In the rumen, calcium propionate dissociates into calcium and propionate ions; the latter is a precursor for glucose synthesis in the liver (Aiello et al., 1989). Propionate participates in feed intake by regulating the liver neural system (Anil and Forbes, 1988). However, the results of current studies indicate that calcium propionate supplementation has inconsistent effects on dry matter intake. Calcium propionate supplementation $\left(200 \mathrm{~g} \cdot \mathrm{day}^{-1}\right)$ did not affect feed intake in the present study (Table 2), which is consistent with the results in dairy cattle (Beem, 2003; DeFrain et al., 2004; Liu et al., 2009b) and lambs (Lee-Rangel et al., 2012). However, many inconsistent effects of calcium propionate supplementation on dry matter intake have also been reported. McNamara and Valdez (2005) stated that calcium

Table 2. Effect of dietary calcium propionate supplementation on growth performance

\begin{tabular}{lrrrr}
\hline \multirow{2}{*}{ Indices } & \multicolumn{2}{l}{ Treatments } & \multirow{2}{*}{ SEM } & \multirow{2}{*}{$P$} \\
\cline { 2 - 3 } & \multicolumn{1}{c}{$\mathrm{CG}$} & \multicolumn{1}{c}{$\mathrm{CaP}$} & & \\
\hline Initial body weight, $\mathrm{kg}$ & 634.2 & 637.1 & 22.36 & 0.93 \\
Final body weight, $\mathrm{kg}$ & 676.3 & 682.8 & 24.18 & 0.85 \\
DMl, $\mathrm{kg} \cdot$ day $^{-1}$ & 9.26 & 9.56 & 0.24 & 0.90 \\
$\mathrm{ADG}, \mathrm{kg} \cdot$ day $^{-1}$ & 0.82 & 0.90 & 0.09 & 0.58 \\
FCR & 11.29 & 10.62 & 1.33 & 0.61 \\
\hline
\end{tabular}

$\mathrm{CaP}$ - experimental group, CG - control group, DMI - dry matter intake, ADG - average daily gain, FCR - feed conversion ratio 
propionate supplementation $\left(125 \mathrm{~g} \cdot\right.$ day $\left.^{-1}\right)$ increased the DM intake of dairy cattle by $11 \%$ prepartum and by $13 \%$ post partum. Similarly, Villalba et al. (1996) found that supplementing calcium propionate at $8.3 \mathrm{~g} \cdot$ day $^{-1}$ increased the feed intake of lambs fed poor quality straw, whereas supplementation at 16.6 $\mathrm{g} \cdot$ day $^{-1}$ decreased feed intake. Nevertheless, some authors also observed that calcium propionate supplementation depressed feed intake (Rigout et al., 2003; Bradford and Allen, 2007). Therefore, we can suppose that inconsistent effects of calcium propionate supplementation on dry matter intake may depend on the nutrition level of basic diets and the doses of calcium propionate supplementation.

The results of the present investigation showed that calcium propionate supplementation did not affect average daily weight gain (ADG) during the experimental periods $(P>0.05)$. Similarity, LeeRangel et al. (2012) also found that supplementing $10 \mathrm{~g} \cdot \mathrm{kg}^{-1}$ calcium propionate to lambs fed $55 \%$ and $65 \%$ concentrate did not affect the ADG. Whitney et al. (2000) observed a greater ADG in calves that was associated with increased ruminal propionate production. The propionate concentrate was not significantly different between the treatments (CG: $20.84 \mathrm{vs} \mathrm{CaP} 21.06 \mathrm{mmol} \cdot 1^{-1} ; P=0.91$; data is not showed in manuscript). Therefore, no effect of calcium propionate on ADG in the present study was expected because the high concentrate diets supply so much ruminal propionate that adding $\mathrm{Ca}$ propionate does not significantly increase ruminal propionate concentration.

\section{Effect of dietary calcium propionate supplementation on meat quality}

As shown in Table 3, calcium propionate supplementation did not affect the variables related to meat quality $(P>0.05)$. Supplementation of this compound to a high-energy diet for finishing steers significantly decreased $(P<0.05)$ the erucic acid content and led to a decreasing tendency in the PUFA content $(0.05<P<0.1)$ compared with that of the control group (Table 4). No significant difference was found in the other indicators of meat fatty acid composition between the treatments $(P>0.05$; Table 4$)$.

Previous studies reported lower PUFA contents in grain-fed beef compared with grass-fed beef (Yang et al., 2002; Noci et al., 2005). Jiang et al. (2013) also found that the PUFA content of beef fed a finishing diet at $70 \%$ concentrate was higher than those fed at $85 \%$ concentrate. These results are probably caused by differences between treatments in PUFA biohydrogenation at the ruminal level.
Table 3. Effect of dietary calcium propionate supplementation on meat quality

\begin{tabular}{|c|c|c|c|c|}
\hline \multirow{2}{*}{ Indices } & \multicolumn{2}{|c|}{ Treatments } & \multirow{2}{*}{ SEM } & \multirow{2}{*}{$P$} \\
\hline & $\overline{C G}$ & $\mathrm{CaP}$ & & \\
\hline $\mathrm{pH}$ & 5.12 & 5.12 & 0.31 & 0.85 \\
\hline Drip loss, \% & 13.98 & 14.14 & 0.59 & 0.85 \\
\hline Cooking loss, $\%$ & 25.31 & 25.91 & 1.21 & 0.72 \\
\hline Warner-Bratzler shear, WBS, kg & 4.18 & 4.82 & 0.48 & 0.35 \\
\hline Water, \% & 69.11 & 68.82 & 1.4 & 0.89 \\
\hline Protein/DM, \% & 61.06 & 60.67 & 2.541 & 0.91 \\
\hline Fat/DM, \% & 34.84 & 36.41 & 2.697 & 0.68 \\
\hline Ash/DM, \% & 3.00 & 2.95 & 0.155 & 0.82 \\
\hline
\end{tabular}

CaP, CG - see Table 2

Table 4. Effect of dietary calcium propionate supplementation on meat fatty acids composition

\begin{tabular}{|c|c|c|c|c|}
\hline \multirow{2}{*}{$\begin{array}{l}\text { Fatty acid, } \\
\mathrm{mg} \cdot \mathrm{g}^{-1}\end{array}$} & \multicolumn{2}{|c|}{ Treatments } & \multirow{2}{*}{ SEM } & \multirow{2}{*}{$P$} \\
\hline & $\overline{C G}$ & $\mathrm{CaP}$ & & \\
\hline C12:0 Lauric & 0.16 & 0.15 & 0.0208 & 0.74 \\
\hline C14:0 Myristic & 7.30 & 7.53 & 0.784 & 0.84 \\
\hline C14:1 Myristoleic & 1.98 & 2.15 & 0.3371 & 0.73 \\
\hline C15:0 Pentadecanoic & 0.77 & 0.74 & 0.0683 & 0.74 \\
\hline C16:0 Palmitic & 69.22 & 67.93 & 5.1565 & 0.86 \\
\hline C16:1 Palmitoleic & 10.32 & 9.99 & 1.0002 & 0.82 \\
\hline C17:0 Heptadecanoic & 2.02 & 1.94 & 0.1664 & 0.76 \\
\hline C17:1 Heptadecenoic & 1.41 & 1.36 & 0.0985 & 0.76 \\
\hline C18:0 Stearic acid & 33.83 & 30.12 & 2.7171 & 0.35 \\
\hline C18:1t trans-Octadecenoic & 108.05 & 106.16 & 8.3472 & 0.87 \\
\hline C18:1c Oleic & 108.33 & 114.53 & 10.1621 & 0.66 \\
\hline C18:2t trans-Linolelaidic & 0.20 & 0.16 & 0.0396 & 0.51 \\
\hline C18:2c Linoleic & 4.44 & 4.03 & 0.2074 & 0.18 \\
\hline C20:0 Arachidic & 0.24 & 0.22 & 0.0209 & 0.50 \\
\hline C20:1n9 Eicosenoic & 0.49 & 0.46 & 0.0419 & 0.63 \\
\hline C18:3n3 a-Linolenic & 0.30 & 0.21 & 0.0396 & 0.14 \\
\hline C22:1n9 Erucic & 0.35 & 0.30 & 0.0157 & 0.03 \\
\hline C22:2 Docosadienoic & 0.52 & 0.48 & 0.031 & 0.40 \\
\hline TFA & 348.47 & 349.93 & 22.6210 & 0.65 \\
\hline SFA & 113.55 & 108.63 & 8.2144 & 0.68 \\
\hline MUFA & 230.93 & 234.96 & 16.1964 & 0.99 \\
\hline PUFA & 5.45 & 4.88 & 0.2171 & 0.06 \\
\hline Omega-3 & 0.30 & 0.21 & 0.0396 & 0.14 \\
\hline Omega-6 & 4.64 & 4.19 & 0.2186 & 0.15 \\
\hline Omega-9 & 0.84 & 0.76 & 0.0414 & 0.20 \\
\hline
\end{tabular}

CaP, CG - see Table 2; TFA - total fatty acids, SFA - saturated fatty acids, MUFA - monounsaturated fatty acids, PUFA - polyunsaturated fatty acids

Neat et al. (1981) reported that the development of the increased capacity for chain shortening and oxidation of erucic acid in the liver of rats fed diets high in erucic acid (C22:1) coincides in time with the development of an increased peroxisomal capacity for fatty acid oxidation. Osmundsen et al. (1979) found that incubation of peroxisomes isolated from hepatocytes with erucoyl-CoA leads to the formation of the same shortened products. So the increased mRNA expression of PPARG in group $\mathrm{CaP}$ in the 
present study could be hypothesized to reflect a higher peroxisomal capacity for shortening and oxidation of erucic acid in the $\mathrm{CaP}$ group, thus leading to lower erucic acid levels in meat compared with the CG.

\section{Effect of dietary calcium propionate supplementation on the expression of $\mathrm{mRNA}$ of adipogenesis genes in muscle}

Marbling is an important factor determining beef quality. Duarte et al. (2013) found that increased mRNA expression of PPARG and CEBPA resulted in the intramuscular fat (IMF) content being greater in Wagyu muscle than in Angus muscle. Transcriptional remodelling leads to the activation of a series of adipocyte-related genes that cause adipocyte differentiation. Transcription factors, such as PPAR $\gamma$ and $\mathrm{C} / \mathrm{EBP} \alpha$, participate in preadipocyte differentiation and interact to generate fully mature adipocytes (Evan and Ormond, 2006). C/EBP $\alpha$ is a transactivator of PPAR $\gamma$, and both transcription regulators act together to promote adipogenesis (Wu et al., 1999).

In the present study, calcium propionate supplementation of a high-energy diet significantly increased the mRNA expression of both PPARG and $C E B P A$ in the experimental group (CaP) compared with the control group, $\mathrm{CG}(P<0.05$; Figure 1). Wan et al. (2009) also found that propionate significantly increased the expression of PPARG and CEBPA mRNA of cultured fat cells of the bovine longissimus dorsi muscle. In addition, Moisá et al. (2014) found that high-starch diets could trigger upregulation of the PPAR $\gamma$ signalling network in longissimus lumborum muscle tissue. Therefore, adding calcium propionate could trigger upregulation of the PPARG and CEBPA mRNA expression levels, which could cause long-term activation of adipogenesis.

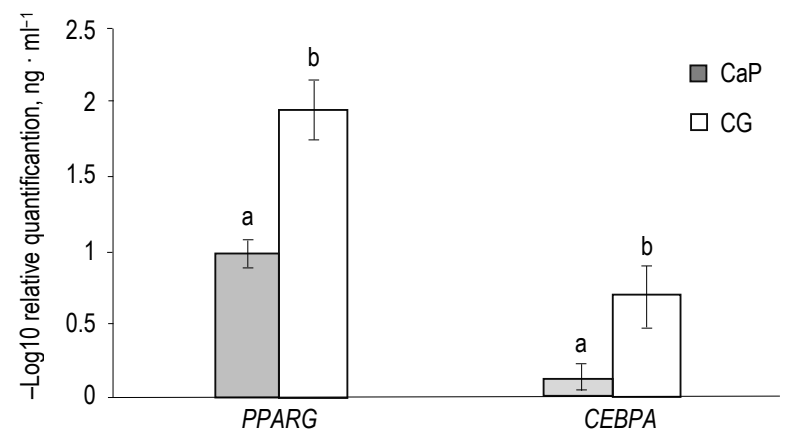

Figure 1. Effect of dietary calcium propionate supplementation on peroxisome proliferator-activated receptor $\mathrm{Y}$ (PPARG), CCAAT/ enhancer binding protein a (CEBPA) mRNA relative expression (CaP - experimental group; CG - control group); ab columns of different groups ( $\mathrm{CaP}, \mathrm{CG}$ ) with different letter above differ significantly $(P \leq 0.05)$ from each other examined gene, separately
The intramuscular fat content was not, however, significantly different between treatments $(P>0.05$; Table 3) mainly because the quantity of calcium propionate supplementation and the duration of the experiment were not sufficient to achieve significant effects based on the high-concentrate diets used in the present study. This is in accordance with the study of Mach et al. (2009), who found that supplementing another energy substance, glycerine, to Holstein bulls fed high-concentrate diets also had no effects.

\section{Conclusions}

The results indicated that calcium propionate supplementation could improve beef quality though increasing the mRNA expression of adipogenic genes.

\section{Acknowledgements}

This study was supported by grants from the National Natural Science Foundation of China (No. 31372335) and the Earmarked Fund for Modern Agro-Industry Technology Research System (Beef Cattle and Yaks, CARS-38) and The Beijing municipal commission of education project (201202910411136).

\section{References}

Aiello R.J., Armentano L.E., Bertics S.J., Murphy A.T., 1989. Volatile fatty acid uptake and propionate metabolism in ruminant hepatocytes. J. Dairy Sci. 72, 942-949

Anil M.H., Forbes J.M., 1988. The roles of hepatic nerves in the reduction of food intake as a consequence of intraportalsodium propionate administration in sheep. Exp. Physiol. 73, 539-546

AOAC, 1999. Association of Official Analytical Chemists, Official Methods of Analysis. $16^{\text {th }}$ Edition. Arlington, VA

Beem A.E., 2003. Use of urine $\mathrm{pH}$ to predict incidence of ketosis in transition dairy cows. M.S. Thesis. Louisiana State University, Baton Rouge, LA (USA)

Bergman E.N., 1975. Production and utilization of metabolites by the alimentary tract as measured in portal and hepatic. In: I.W. McDonald, A.C.I. Warner (Editors). Digestion and Metabolism in the Ruminant. University of New England Publishing Unit. Armidale, pp. 292-305

Bradford B.J., Allen M.S., 2007. Phlorizin administration does not attenuate hypophagia induced by intraruminal propionate infusion in lactating dairy cattle. J. Nutr. 137, 326-330

DeFrain J.M., Hippen A.R., Kalscheur K.F., Jardon P.W., 2004. Feeding glycerol to transition dairy cows: effects on blood metabolites and lactation performance. J. Dairy Sci. 87, 4195-4206

Duarte M.S., Paulino P.V.R., Das A.K., Wei S., Serão N.V.L., Fu X., Harris S.M., Dodson M.V., Du M., 2013. Enhancement of adipogenesis and fibrogenesis in skeletal muscle of Wagyu compared with Angus cattle. J. Anim. Sci. 91, 2938-2946

Evan D.R., Ormond A.M., 2006. Adipocyte differentiation from the inside out. Mol. Cell. Biol. 7, 885-896 
Hong Y.H., Nishimura Y., Hishikawa D. et al., 2005. Acetate and propionate short chain fatty acids stimulate adipogenesis via GPCR43. Endocrinology 146, 5092-5099

Issemann I., Green S., 1990. Activation of a member of the steroid hormone receptor superfamily by peroxisome proliferators. Nature $347,645-650$

Jiang T., Mueller C.J., Busboom J.R., Nelson M.L., O'Fallon J., Tschida G., 2013. Fatty acid composition of adipose tissue and muscle from Jersey steers was affected by finishing diet and tissue location. Meat Sci. 93, 153-161

JMGA, 1988. New Beef Carcass Grading Standards. Japan Meat Grading Association. Tokyo (Japan)

Kutoba N., Terauchi Y., Miki H., Tamemoto H., Yamauchi T., Komeda K., 1999. PPAR gamma mediates high-fat diet-induced adipocyte hypertrophy and insulin resistance. Mol. Cell. 4, 597-609

Lee S.H., Hossner K.L., 2002. Coordinate regulation of ovine adipose tissue gene express by propionate. J. Anim. Sci. 80, 2840-2849

Lee-Rangel H.A., Mendoza G.D., González S.S., 2012. Effect of calcium propionate and sorghum level on lamb performance. Anim. Feed Sci. Tech. 177, 237-241

Lekstrom H.J., Xanthopoulos K.G., 1998. Biological role of the CCAAT/ enhancer-binding protein family of transcription factors. J. Biol. Chem. 273, 28545-28548

Liu Q., Wang C., Guo G., Yang W.Z., Dong K.H., Huang Y.X., Yang X.M., He D.C., 2009a. Effects of calcium propionate on rumen fermentation, urinary excretion of purine derivatives and feed digestibility in steers. J. Agr. Sci. 14, 201-209

Liu Q., Wang C., Yang W.Z., Guo G., Yang X.M., He D.C., Dong K.H., Huang Y.X., 2009b. Effects of calcium propionate supplementation on lactation performance, energy balance and blood metabolites in early lactation dairy cows. J. Anim. Physiol. Anim. Nutr. 1111, 605-614

Mach N., Bach A., Devant M., 2009. Effects of crude glycerin supplementation on performance and meat quality of Holstein bulls fed high-concentrate diets. J. Anim. Sci. 87, 632-638

McNamara J.P., Valdez F., 2005. Adipose tissue metabolism and production responses to calcium propionate and chromium propionate. J. Dairy Sci. 88, 2498-2507

Mir P.S., Bailey D.R.C., Mir Z., Entz T., Jones S.D.M., Rober T.W.M., Weselake R.J., Lozeman F.J., 1999. Growth, carcass and meat quality characteristics of beef cattle with 0,50 and 75 percent Wagyu genetic influence. Can. J. Anim. Sci. 79, 129-137

Moisá S.J., Shike D.W., Faulkner D.B., Meteer W.T., Keisler D., Loor J.J., 2014. Central role of the PPARy gene network in coordinating beef cattle intramuscular adipogenesis in response to weaning age and nutrition. Gene Regul. Syst. Bio. 8, 17-32

Neat C.E., Thomassen S.M., Osmundsen H., 1981. Effects of high-fat diets on hepatic fatty acid oxidation in the rat. Biochem. J. 196, 149-159

Nishimura T., Hattori A., Takahashi K., 1999. Structural changes in intramuscular connective tissue during the fattening of Japanese black cattle: effect of marbling on beef tenderization. J. Anim. Sci. 77, 93-104

Noci F., Mona H.F.J., French P., Moloney A.P., 2005. The fatty acid composition of muscle fat and subcutaneous adipose tissue of pasture-fed beef heifers: Influence of the duration of grazing. J. Anim. Sci. 83, 1167-1178
NRC, 2000. Nutrient Requirements of Beef Cattle. 7th Edition. National Academic Press. Washington, DC

O'Fallon J.V., Busboom J.R., Nelson M.L., Gaskins C.T., 2007. A direct method for fatty acid methyl ester synthesis: Application to wet meat tissues, oils, and feed stuffs. J. Anim. Sci. 85, $1511-1521$

Osmundsen H., Neat C.E., Norum K.R., 1979. Peroxisomal oxidation of long chain fatty acids. FEBS Lett. 99, 292-296

Rigout S., Hurtaud C., Lemosquet S., Bach A., Rulquin H., 2003. Lactational effect of propionic acid and duodenal glucose in cows. J. Dairy Sci. 86, 243-253

Rosen E.D., Sarraf P., Troy A.E., Bradwin G., Moore K., Milstone D.S., Spiegelman B.M., Mortensen R.M., 1999. PPAR gamma is required for the differentiation of adipose tissue in vivo and in vitro. Mol. Cell. 4, 611-617

Smith S.B., Crouse J.D., 1984. Relative contributions of acetate, lactate and glucose to lipogenesis in bovine intramuscular and subcutaneous adipose tissue. J. Nutr. 114, 792-800

Smith S.B., Go G.W., Johnson B.J., Chung K.Y., Choi S.H., Sawyer J.E., Silvey D.T., Gilmore L.A., Ghahramany G., Kim K.H., 2012. Adipogenic gene expression and fatty acid composition in subcutaneous adipose tissue depots of Angus steers between 9 and 16 months of age.J. Anim. Sci. 90, 2505-2514

USDA, 1989. Official United States Standards for Grades of Carcass Beef. Agricultural Marketing Service. USDA, Washington, DC

Van Soest P.J., Robertson J.B., Lewis B.A., 1991. Methods for dietary fibre, neutral detergent fibre and nonstarch carbohydrates inrelation to animal nutrition. J. Dairy Sci. 74, 3583-3597

Villalba J.J., Frederick D., Provenza F.D., 1996. Preference for flavored wheat straw by lamb conditioned with intraruminal administrations of sodium propionate. J. Anim. Sci. 74, 2362-2368

Wan R., Du J.P., Ren L.P., Meng Q.X., 2009. Selective adipogenic effects of propionate on bovine intramuscular and subcutaneous preadipocytes. Meat Sci. 82, 372-378

Wheeler T.L., Cundiff L.V., Shackelford S.D., Koohmaraie M., 2004. Characterization of biological types of cattle (Cycle VI): carcass, yield, and longissimus palatability traits. J. Anim. Sci. 82,1177-1189

Whitney M.B., Hess B.W., Burgwald-Balstad L.A., Sayer J.L., Tsopito C.M., Talbott C.T., Hallford D.M., 2000. Effects of supplemental soybean oil level on in vitro digestion and performance of prepubertal beef heifers. J. Anim. Sci. 78, 504-514

Wu Z., Rosen E.D., Brun R., Hauser S., Adelmant G., Troy A.E., McKeon C., Darlington G.J., Spiegelman B.M., 1999. Crossregulation of C/EBP alpha and PPAR gamma controls the transcriptional pathway of adipogenesis and insulin sensitivity. Mol. Cell. 3, 151-158

Xiong Y., Miyamoto N., Shibata K., 2004. Short-chain fatty acids stimulate leptin production in adipocytes through the $\mathrm{G}$ proteincoupled receptor GPCR41. Proc. Nat. Acad. Sci. USA 101, 1045-1050

Yang A., Lanari M.C., Brewster M., Tume R.K., 2002. Lipid stability and meat color of beef from pasture- and grain-fed cattle with or without vitamin E supplement. Meat Sci. 60, 41-50 